\title{
CONSIDERING NEW PUBLIC GOVERNANCE POSSIBILITIES IN CENTRAL AND EASTERN EUROPE
}

\author{
Iveta Reinholde, Arvydas Guogis, Vainius Smalskys, \\ Skaidrė Žičkienè, Daniel Klimovsky \\ University of Latvia (Latvia), Mykolas Romeris University (Lithuania), \\ Šiauliai University (Lithuania), Comenius University (Slovakia)
}

\begin{abstract}
There is presented and shortly evaluated in the article the basic development of public administration in Central and Eastern European countries by indicating the most important stages of modernization in the light of prevailing theoretical paradigms. The authors identify three main stages - traditional public administration, New Public Management and New Public Governance, which are sometimes interrelated or contradicting to each other at the same time. New Public Governance is the most wanted and admired paradigm in Central and Eastern Europe, especially because of its social attractiveness and sensitivity, but it is still lacking more certain methods and tools to be implemented in practice. New Public Management, because of its capitalist entrepreneurship spirit, only partially changed public administration model. It was not an excellent model of reform, that's why it is possible to point to NPM as socially irresponsible reform of the public sector. At the same time the principles of New Public Governance are orientated not only to the participation of citizens and citizens' groups, but also to the development of social welfare, social quality, social responsibility and social justice. These are the values, which are most necessary to overcome the side effects of modernization. It is possible to draw a conclusion about this article, that by developing and presenting the more progressive principles and values of NPG, such as openness, transparency, social justice, social quality, absence of corruption and more active non-governmental organisations, Central and Eastern European countries could achieve more stable democratic development, as well as elimination or minimization of the negative impact of New Public Management for various spheres of public sector's reforms.

KEYWORDS: hierarchical (Weberian) traditional public administration, New Public Management, New Public Governance, modernization.
\end{abstract}

\section{Anotacija}

Straipsnyje pateikiami ir įvertinami svarbiausi viešojo administravimo vystymosi bruožai Centrinèje ir Rytų Europoje, pabrèžiant esminius modernizacijos laikotarpius vyraujančių teorinių paradigmų kontekste. Autoriai identifikuoja tris svarbiausias paradigmas: tradicinis hierarchinis viešasis administravimas, naujoji viešoji vadyba ir naujasis viešasis valdymas, kurie kartais tarpusavyje susiję ar vienas kitam prieštarauja. Nepaisant ịspejjimų dèl praktikos stokos, naujoji viešoji vadyba kurị laiką buvo patrauklus administravimo modelis dèl politikos formavimo ir igyvendinimo atskyrimo. Kartu su kontraktine vadyba naujoji viešoji vadyba kūrè tam tikrą iliuziją, kad ji visiškai pakeis viešojo administravimo pobūdị, bet, kaip reformų modelis, nenubrěžè aiškios vystymosi krypties, o dèl savo kapitalistinès verslininkiškos prigimties rizikas viešajam sektoriui formavo kaip socialiai neatsakingas modelis. Dėl šių priežasčių XXI amžiaus pradžioje ị politikos ir administravimo areną ịžengé naujasis viešasis valdymas, kuris tapo labiausiai laukiama paradigma Centrinèje ir Rytų Europoje. Jis ypač pageidautas dèl savo socialinio patrauklumo ir subtilumo. Nors teoriškai naujasis viešasis valdymas yra logiškai nepriekaištingai pagrindžiamas ir vertybiškai neprieštaringas modelis, praktiškai jam vis dar trūksta konkretesnių ịgyvendinimo metodų.

PAGRINDINIAI ŽODŽIAI: tradicinis hierarchinis (véberinis) viešasis administravimas, naujoji viešoji vadyba, naujasis viešasis valdymas, modernizacija. 
Iveta Reinholde, Arvydas Guogis, Vainius Smalskys, Skaidre Žičkienė, Daniel Klimovsky

DOI: http://dx.doi.org/10.15181/tbb.v85i2.2187

\section{Introduction}

Public administration is a rather new discipline on the map of science. However, there are a few breakeven points changing the principles and models in the scientific discipline of public administration, as compared to other social sciences (Kettle, 2000). Researchers single out two of them: New Public Management (NPM) and New Public Governance (NPG). The theoretic grounding of the traditional hierarchical administration was formed by the research and provisions of von Stein, Weber and their followers (Szczepankowski, 2009). By modernising public administration and orienting the principles of its activities towards the practice of business management, contributed to a scientific basis for the formation of the New Public Management (NPM) (Hood, 1991; Osborne and Gaebler, 1992). Reforms of NPM expanded the opportunities to involve citizens in governance and to convert public agencies in business like organisations with entrepreneurial leadership, i.e. to transfer management concepts from business organizations to public organizations as the basic principle of their operations (Krukowski, Siemiński, 2018). Emphasis on inputs and outputs has become the brand of the NPM. However, scholars like Kooiman (2000), Denhardt and Denhardt (2007) on governance, contributed largely for the paradigm of NPG which focuses on civil participation in governance. However, almost no research has been done associating the NPG with the development of social welfare, thus exploring a link between public administration and development. However, in Central and Eastern European (CEEC), as transition countries, the elements of all three models (i.e, traditional, NPM, and NPG) coexist in practice. Therefore, it is worth to explore what kind of conditions is important for those elements to achieve the goals for which they were designed. This is especially important for CEEC which faced triple reforms at the beginning of 90ties and reform models were applied without a proper adjustment (Hesse, 1993). At the same time, researches on NPM mainly explain Western experience while CEEC, due to complexity of reforms, has been left unexplained (Koht and Reinholde, 2015). At the same time, Kovač (2015) pointed out that the main deficiency of traditional public administration is a failure to react to the changing and complex society, while NPM endangers equality and might create a ground for corruption, technocracy and corporatism. Therefore, the main research question is whether NPG might be an attractive model for CEEC to escape from problems and deficiencies of traditional public administration and NPM. A basic problem of both NPM and NPG is their clearness for non-Anglo-Saxon audience. In CEEC, there is no single country which implemented the principles of one of these two concepts 
in a successful way (Drechsler and Kattel, 2008; Drechsler, 2009; Drechsler et al., 2013; Malíková and Jacko et al., 2013). More precisely, many CEEC leaned on the New Public Management paradigm in the 1990s, since it has been realized that classic bureaucracy, based on public management (Pinterič, 2011), failed in terms of meeting its goals and significantly endangered public finances. NPM has often been popularly contrasted with the European public administration. The critical approaches of some authors - e.g. Pollitt and Bouckaert $(2004 ; 2017)$ - introduced a term "Neo-Weberian State" to reflect European conditions which are different in comparison with Anglo-American conditions, the NPM and NWS are sometimes understood as similar in terms of their content (Dunn and Miller, 2007). As it is stated by Rupnik (2000) and the authors of the present article, despite the fact that they had periods of communist parties' regimes in their post-second world war developments, they have always been very different (obviously, there are missing links between Slovakia and Albania, between Latvia and Hungary, between Poland and Slovenia or between Lithuania and Croatia). From this perspective one could expect that at least some of those countries succeeded in implementation of the principles of either NPM or NPG (Bouckaert et al., 2008).

\section{Methods of Research}

This article is of review type, and it was used a descriptive analytical method in it. Descriptive analytical method is often used for research of social processes (in this case of public governance) and their contemporary tendencies, or new phenomenas, by picking up the information about the present situation, and wanting to have a comprehensive view about the analysed phenomena. In our case of research, there is analysed and evaluated the "New Public Governance" phenomena, which is socially responsible and orientated to citizens and their groups. And it is analysed as the alternative to "New Public Management", which emerged from business management. After analysis of the overall picture of NPM and NPG (as phenomenas), there is used the comparative method. This method is taken as supportive for the coherence of information about administrative reforms and their features in various Central and Eastern European countries. In the investigated case many countries in Central and Eastern Europe are having the complicated trajectories of their public sectors reforms and implying the negative influence to various spheres of social life. This is the main reason for the authors to draw a conclusion, that New Public Governance can serve as one of the models for creating the socially responsible system of public power. 
Iveta Reinholde, Arvydas Guogis, Vainius Smalskys, Skaidre Žičkienė, Daniel Klimovsky

\section{Research Results}

\subsection{Modernising public administration - from traditional public adminis- tration to NPM}

Public administration as an academic discipline has existed for slightly more than a century. One of the most crucial scholars, who influenced the public administration in a very significant way, was Max Weber, who developed an ideal model of bureaucracy in his book Wirtschaft und Gesselschaft (Weber, 1976), which was originally published in 1922 (Hausner, 2008). At that time, it was a big breakthrough in social and behavioural sciences allowing to form the main postulates of public administration as a separate academic discipline. Ideas of Max Weber also singled out public administration from other social sciences: sociology, economics, law, management and political science. However, one cannot forget the unique contributions from Lorenz von Stein, especially in his book Die Verwaltungslehre, and Woodrow Wilson, the author of the worldwide famous essay The Study of Administration, who had created a base of public administration as an academic discipline already in the end of the 19th century (Klimovský, 2014). The work of these three scholars influenced plenty of other scholars in the following decades. Despite huge criticism - represented for instance by Appleby (1949), Crozier (1964), Mayo (1945), Merton (1940), Selznick (1943), Simon (1976), Svara (2001), Daneshfard, Aboalmaali (2016) - most of the present concepts have their roots in thoughts developed by von Stein, Wilson and Weber (Kickert and Stillman, 1996; Rugge, 2003; Rutgers, 1997; 2003). In the continental administrative tradition, an ideal model of bureaucracy means the domination of hierarchic relations and accountability of the subordinates to the working persons, who are (chiefs) rooted higher in the hierarchy (e. g. heads of units, directors of departments, etc.) in Russia and France (e.g. Dennewitz, 1948; Klimovský, 2009a). To make this kind of bureaucratic apparatus function smoothly, procedures and rules must be foreseen, to which the subordinates must adhere to. Weber thought that a perfect organization of a hierarchic pyramid can effectively contribute to the stability of the country, the loyalty of the society, and the qualification and competence of the employees (e.g. Hausner, 2008; Patapas, 2010).

By modernizing the public sector, elements of vertically integrated hierarchic organisation have been cut for the sake of efficiency. Since hierarchic relations allow dividing responsibility much simpler and faster, the structure of public organization sector will never be horizontal, therefore, in case of certain mistakes or misdemeanour, the activity of the agency will not be paralysed, and the compromised public servants can be sooner substituted by other persons, ensuring the continuity of the activities of the public sector (Patapas, 2010). In addition, the 
classical public administration relies on the system of legal acts and the legal environment, without which the process of public administration would be impossible. This legalistic approach has been typical in many Central and Eastern European countries. Some path dependency can be observed and a legalistic approach is preferred by some stakeholders, and every attempt to modernise public administration reform and implement some new principles is accompanied with a strong bureaucratic resistance. For instance, the "Communist" regime institutions were removed practically immediately after the collapse of the USSR at the beginning of 1990s. However, their replacement with the new system institutions was rather problematic. The main purpose of the political and administrative changes was to redesign political and administrative systems considering their improvement and accommodation to the new social as well as economic conditions (Klimovský, 2009b). However, CEEC have experienced several failures. There was public and political pressure to design the grand reforms and to achieve the quick results, however, in reality, new agencies were developed quite often in a chaotic and non-strategic manner. In addition to this, any administrative model working in the West was assumed as suitable for CEE countries since it provided both: the point of no return to communist type administration and integration into Western political, social and administrative space where the last was even a goal of foreign policy. The traditional hierarchical Weberian model is based on principles of bureaucratic governance: civil servant's professionalism, rationality, work continuity and specialization, hierarchical organization of the institution, formalized rules of activity etc. (e.g. Hausner, 2008; Klimovský, 2014). However, it is necessary to emphasize that formalized rules of activity, expansion of the obligations in the field of public services, and an increasing regulation of economic processes, in the long term, made a negative influence on the effectiveness of administration. A more efficient implementation of public programmes was needed, one that would control these negative tendencies (Smalskys, 2009, p. 35). New Public Management (NPM) was offered as an alternative to traditional hierarchical governance, it focuses towards business management methods as the key methods to solve long lasting effectiveness and expenditure debate. The principles of NPM that appeared in Anglo-Saxon countries (the beginning was the public sector reforms in New Zealand of 1978-1980) were deeply rooted in most Western countries within the next three decades (Smalskys, 2007, p. 40) but with remarkable differences across countries (Pollitt and Bouckaert, 2017). Some countries were more moderate in applying NPM, some countries were more radical. If the traditional Weberian model focused on the processes, the NPM focuses on results first. According to NPM, the results had to be measured in a quantitative way. Out of the five essential public sector functions, including distribution, redistribution, regulation, creation of 
Iveta Reinholde, Arvydas Guogis, Vainius Smalskys, Skaidre Žičkienė, Daniel Klimovsky

institutions and provision of services, the latter function was the most important. More services over a shorter period with lower costs was the credo of the reforms of NPM, also more market orientation in the public sector that will lead to greater cost-efficiency for governments (Siami-Namini, 2020). A top priority was linked to effectiveness (Lane, 2000; Lapuente, Van de Walle, 2020), but according to Hood and Dixon (2015) attempts at assessing the effects of NPM have been hindered by a lack of comparable data. Experience of NPM inspired reforms question in the basic: whether focusing on results does not surpass the aims of reforms (e.g. Drechsler, 2005; Kuhlmann and Fedele, 2010; Lane, 1996; Nemec, 2008; Pollitt et al., 2007; Wollmann and Thurmaier, 2011).

\subsection{Challenging transition to NPG}

For CEE countries, NPM was attractive because it provided a discretion for public servants and gave a chance to try private sector methods in the public agencies. However, already back in 1998, Schick warned the CEE countries to be careful regarding the implementation of NPM. Schick pointed out that NPM offers management reforms and contractual relations which might be dangerous for transition countries with a weak tradition of rule of law inherited in the traditional bureaucratic model (Schick, 1998). However, despite the warnings, NPM was attractive for administration because of the separation of policy implementation from policy making. This, together with a contractual management, created some sort of an illusion that NPM is here to completely change the nature of public administration. Markets, contracts and public services were the concepts having a flavour of modernisation in 1990s. However, later on these NPM characteristics turned out to be the most problematic. So, for example, Latvia has faced serious problems with agencies transferring the idea from UK. Having weak implementation with no proper legal framework, these agencies turned out to be semi-autonomous organisations with weak external control and accountability. Pollit described this as "policy vacuums" (Pollit and Bouckaert, 2004). At the same time, the grand expectation and attractiveness of the NPM was the key factor to change the modernisation direction for public administration in those countries. Further on, Reagan's and Thatcher's reforms in the USA and Great Britain encouraged the collapse of communism in Central and Eastern Europe, however, it did not create an attractive transformational model for post-communist countries. Reforms based on economic liberalism developed a socially insensitive economic model (the implementation of the principles of NPM was also useful in this regard). Reckless chase after profit, overuse of natural resources, collapse of financial pyramids and false aims of postmodernism disarranged the more lively fabric of the society and made the development of social market economy very complicated. In the public 
administration theory, which was influenced by these reforms, descriptive cases prevailed (which were influenced by the New Public Management), and not only they interfered with the development of the new paradigms (e. g. the new public governance) or models, but even intermediary meta-theories, which could connect individual paradigms and cases of public administration as bridges, could not be provided. On the other hand, several decades after the collapse of communism, neoliberal reforms have caused a nostalgic feeling for the Soviet past (or socialist past, for example, in the case of Bulgaria or Slovakia) for a large number of residents of CEE countries. The well-known Lithuanian political scientist Aine Ramonaite, as pointed by Sapetkaite, has noted in her research that approximately 40 per cent of Lithuanian residents feel nostalgic for the Soviet past and the social standards of the time (Sapetkaite, 2014). This once again proves that the persons forming Lithuania's public policy have made an essential mistake (especially in the social and economic policy area) by choosing a marginal (liberal) welfare model, rather than the realization of the economic reforms that are based on social market. The controversial reforms of NPM presupposed the appearance of an alternative of New Public Governance. Pollitt and Bouckaert (2011) introduce a new model that aims to modernize the traditional state apparatus so that it becomes more professional, more efficient, and more responsive to citizens" (Pollitt and Bouckaert, 2011, p. 22; Meneguzzo et al., 2011) also provided a synthetic characterisation of the paradigms of Weberian model, NPM and NPG. The latter, which was oriented towards civil participation in public governance and partnership in public governance, and the development of social welfare, is sometimes called the flip side of the new public management. One of the principles of NPM was the participation of citizens and their communities in governance. While the principles of NPG are not only oriented towards the participation of citizens and groups of citizens, but also to the development of social welfare, social quality, responsibility and justice. Osborne (2006) confirms that NPG is not integral to the NPM, but is rather an alternative discourse in its own right, providing a direction for future modernisation trends. Already back in 1937, Luther Gullick declared POSDCORB principles of administration (planning, organising, staffing, directing, coordinating, reporting, budgeting) (Raipa, 2009), which, according to the principles of NPG, will acquire a totally different view - more open, more democratic and more pluralist. This is a humane paradigm of administration, for which, economic-social safety, social insertion, social cohesion and social empowerment are the most important elements. Not only the results, but also the process for reaching the results is important for this kind of public administration. If that is an advanced normative model of administration, - what would the practice and the opportunities to apply this kind of model be? On the other hand, can countries in which an effective traditional-hie- 
Iveta Reinholde, Arvydas Guogis, Vainius Smalskys, Skaidre Žičkienė, Daniel Klimovsky

rarchic model was not fully implemented or there was resistance to the implementation of NPM reforms, adapt to the principles of NPG? Maybe NPG might be an attractive model for CEEC to escape from problems and deficiencies of traditional public administration and NPM, when those models faced the complex reality of the post-communist states? Whether NPG can be implemented without an evaluation of weaknesses and strengths of previous models?

\subsection{NPG - new values?}

Comparing NPM and NPG, NPG comes on the arena in CEEC on a more modest way. First, of all, public servants and academia needs to understand the unique character of NPG by asking "what is new?". Secondly, CEEC countries have already noticed that NPM and NPG overlapped for some elements. Thirdly, how NPG might change the practice, which may become a crucial factor? By expanding and providing a more detailed description of NPG principles and values like openness, transparency, social justice, social responsibility, social quality, absence of corruption and much more, active non-governmental organizations are specific for this paradigm. These values not only improve the microclimate of team (community) management, but also make positive influence on customer service. Denhardt and Denhardt (2000) called this new trend "New Public Service". It means redounding towards the client, as the user and evaluator of the service. All information is openly stated to him, one openly shares the information about the hardships and obstacles arising, common decisions are sought. In this case, asymmetric information is not a problem. Hence the transactional costs of provision of the service also significantly decrease, the necessity to hire additional employees for providing a better service disappears. Demmke et al. (2006), debating about the priorities of the public management reform in Europe, reveals that for the transition states, open government and ethics/code of conduct have a great influence (Meneguzzo et al., 2011). In the context of modernizing the public sector, a number of the NPM aims would not correspond to the needs of public agencies, and sometimes would not conform to the needs of clients (Guogis, 2013a). Public managers have obtained more discretion, but the possibility of making mistakes has increased. Without prior research and consulting the subordinates and representatives of the civil society, the possibility to make a mistake would significantly increase. Whatever the relation between the aim and the means exists, NPM offered a quantitatively calculated and measured approach. At the same time, NPM, by increasing competitiveness and the search for results, can jeopardize social justice, social responsibility and humanistic values. Will a social worker, rushing to provide a client with a service at home, really meet the client's expectations? A service standard foresaw 15 minutes for home-based care, but does it really provide quality? The $3 \mathrm{E}$ concept 
which consists of economy, efficiency and effectiveness, should be seen as insufficient to describe the efficiency of the overall public administration modernization tendencies in the CEE countries. It may be complemented by the $4 \mathrm{E}$ component, $\mathrm{i}$. e. equity (social justice). In NPM reforms, economy and efficiency are associated with the degree of achievement of a positive outcome between the costs and results, while effectiveness - a degree of achievement of goals when working according to the principles of NPM might significantly decrease (Puškorius, 2002). More attention to $6 \mathrm{E}$ - in addition of equity, equality, and ethics would make the reforms easier from a social perspective (Guogis, 2013b). All CEEC have faced triple reforms, where the market reform had a tremendous impact on social policy resulting in higher social inequality and risk of poverty. Thus, emphasis on $6 \mathrm{E}$ and NPG inspired improvements might minimise externalities of modernisation. NPM methods like one-stop shop, priority planning, total quality management, and medium term budget might produce tangible results. However, all of them, without a social dimension, social justice and social equality, can do more harm on public administration than be useful - and not only in terms of servicing clients but also of the employees in the public sector. A considerable increase in workload, both for the head and his subordinates, can do harm on employees' health, form inadequate competitive environment, limit open communication and benevolent sharing of information. If each unit of the organization competes with another one, and their employees (who are result-oriented) also compete on the individual level, this can turn into an unnecessary contradiction of all against all and form an intolerable microclimate in the team (community) (Wieworka, 2013, p. 699-700). Whereas, in Australia, on the state level, once the result-oriented reforms of civil service were implemented, a psychological tension developed among the employees, and simultaneously, work quality decreased (Minkevičius and Smalskys, 2008). Australia is an Anglo-Saxon country, one of the initiators of the New Public Management reform in the world. Its society and the employees live under the conditions of marginal (liberal) welfare, and still the reform, which was oriented towards business management methods, caused problems for civil servants. What is there to say about analogous reforms in post-communist countries or in the public sector organizations of Continental European countries which function under redistributory or corporate (i.e. socially safe) standards of welfare? Competition should have such boundaries that, without crossing them, the employee would feel safe, secure, optimistic and would wish to help colleagues rather than disturb them. The synergy of the team (community) can produce much better results than an organization that is based on individualized activity. Therefore, not by chance, various theories and practices are now being created in the West to encourage group work - without a clear hierarchy, by eliminating the majority of New Public Management princi- 
ples. The forms of this group work vary - from focus groups and couching as conflict management to partnership leadership, where all the participants in the direct sense are seated at the table and then start looking for decisions. The authors claim that participatory research can be an another method of such democratic search for decisions, when the respondents, who are mostly members of various communities or even marginalized groups, together with the researcher look for decisions how to escape the bad situation (Poviliūnas, 2003). In all of these cases employees or clients benevolently share information. They merely complement each other and reach a collective synergy for most effective decisions or work results. Even though the reforms of new public management encouraged financial support of leading employees or those, who have made the biggest influence in the activities of the organization and this definitely was not a bad choice, however, the results achieved in synergy can equally lead to bigger earnings and, what is most important, they can better motivate those in the company lagging behind by making them to try to do better. The benchmarking method existing in the new public management is used to overtake the good practices from other countries and organizations (Vareikyte et al., 2006). On the other hand, in the course of reforms, it was increasingly more dedicated to sharpen competitiveness. Even though employees lagging behind were learning from the advanced ones, according to the authors, the principle of group collective partnership creates a much more motivating environment in the team (community). In our opinion, one can start answering this question only after a short analysis of the reforms of Western countries that were taking place in the previous 30 years. We will see that it was a period of retreat from the principles of welfare state, which was called by some of the authors as the Golden Age (Wincott, 2013; Gallo, Svensson, 2019). When Western welfare states, that were becoming more powerful, were strongly hit by the reforms of neoliberalism, and from the Golden age, they got to the zone which is socially vulnerable and were the social exclusion was increasing. Uncontrolled competition, which is based on selfishness and individualism, caused a lot of social problems. The consequences of neoliberal reforms in Lithuania, Latvia, Slovakia and other post-communist countries were even more painful than in Western countries, since until the reforms of 1990-2000 the system here was occupational, alien, artificial, a totally non vital soviet administrative system, and yet, the transformations from communism to market relations were not based on the principles of social justice. Two conceptions of social welfare prevailed in the post-war Western world: the social-economical paradigm which is based on Catholic (Christian) social teaching, and the conception of social-democratic welfare state (Cousins, 2005). The latter was materialized in public administration at Minnowbrook Conference in 1968, where the question of the importance of social justice and social 
equality in public governance was raised (Klimovský, 2014). To ensure social equality and to eliminate various forms of discrimination of humans, theoretic postulates of New Public Administration were formulated (Zawicki, 2011). However, they were never realized in the form of reforms and they were not broadly supported.

\section{Discussion}

Considering its significance for public administration, the hierarchic Weberian model of administration can be assumed as the most important model of public administration. The NPM that appeared in Anglo-Saxon countries 30 years ago presupposed individualistic approach, which is based on private business methods, distinguishing individual achievements in effectiveness. At the same time, NPM can be a kind of 'dangerous activity' for post-communist countries, where its principles can be irresponsibly used in public sector, when seeking for personal benefits or by focusing on absolutely quantitative, reckless competition-based results. A more suitable paradigm of public administration in such a controversial situation would be NPG. However, owing to the development of reforms of liberal capitalism (in the past 25-30 years in Central and Eastern European countries), only theoretically understandable and acceptable principles of New Public Governance are presupposed. Yet, the discussions of the methods for its implementation are further avoided. The NPM inspired risks are related to corruptive and individualistic relations as well as corruption. These phenomenas emphasise the role of the individual instead of common good. However, this is dangerous in societies where values of individual good and common good are diffused and proper mechanisms of accountability are weak. In reality, in CEEC, elements of all three models (i.e., traditional, NPM, and NPG) co-exist in practice, and since the dynamics of reforms in CEEC were so high because those countries faced triple reforms at the beginning of $90 \mathrm{~s}$, and reform models were applied without a proper adjustment and assessment. A basic problem of both NPM and NPG is their clearness for nonAnglo-Saxon audience. There is no single country in CEEC, which implemented the principles of one of these two concepts in a successful way. Despite warnings and a lack of practice, NPM was attractive for administration because of separation of policy implementation from policy making. This, together with a contractual management, created some sort of an illusion that NPM will completely change the nature of public administration. Since it did not provide a clear future direction, as a great model of reform, NPM became misleading. While the principles of NPG are oriented not only towards the participation of citizens and groups of citizens, but also to the development of social welfare, social quality, responsibility and 
Iveta Reinholde, Arvydas Guogis, Vainius Smalskys, Skaidrẻ Žičkienė, Daniel Klimovsky

justice. These are values desperately needed to overcome externalities of modernization. By expanding and providing a more detailed description of NPG principles and values like openness, transparency, social justice, social responsibility, social quality, absence of corruption and much more active non-governmental organizations, countries of CEEC could achieve both - democratic development and minimisation of negative effects towards market theories for public administration.

\section{Conclusions}

1. It is possible to identify three public administration development stages in Central and Eastern Europe - traditional public administration, New Public Management and New Public Governance, which are sometimes interrelated or contradicting to each other at the same time.

2. Despite warnings and a lack of practice, New Public Management was attractive for administration for some time because of separation of policy implementation from policy making. This, together with a contractual management, created some sort of an illusion that NPM will completely change the nature of public administration.

3. Since New Public Management did not provide a clear future direction, as a great model of reform, NPM became misleading and, because of its capitalist entrepreneurial spirit, it posed a threat for public sector as socially irresponsible model.

4. New Public Governance is becoming the most wanted and admired public administration model nowadays, which is directed against New Public Management shortages with its qualities of openness, transparency, democracy, pluralism, social responsibility, social justice, social quality, anti-corruption and more active non-governmental organizations. Despite its theoretical attractiveness, however, New Public Governance is still lacking the concrete methods of implementation.

\section{References}

Appleby, P. H. (1949). Policy and Administration. Tuscaloosa: University of Alabama Press.

Bouckaert, G. et al. (eds.). (2008). Public Management Reforms in CEE. Bratislava: NISPAcee.

Cousins, M. (2005). European Welfare States. London: Sage.

Crozier, M. (1964). The Bureaucratic Phenomenon. Chicago: University of Chicago Press.

Daneshfard K., Aboalmaali F. S. (2016). Max Weber's Philosophy of Bureaucracy and Its Criticism. International Journal of Scientific Management and Development, Vol. 4, No. 6, p. 214-220.

Demmke, C., Hammerschmid, G., \& Meyer, R. E. (2006). Decentralisation and Accountability as a Focus of Public Administration Modernisation: Challenges and Consequences for Human Resource Management. Maastricht / Brussels: European Institute of Public Administration.

Denhardt, J. V., Denhardt, R. B. (2000). The New Public Service: Serving Rather Than Steering. Public 


\section{CONSIDERING NEW PUBLIC GOVERNANCE POSSIBILITIES IN CENTRAL AND...}

Administration Review, Vol. 60(6), p. 349-359.

Denhardt, J. V., Denhardt, R. B. (2007). The New Public Service: Serving, Not Steering. New York: ME Sharpe.

Dennewitz, B. (1948). Die Systeme des Verwaltungsrechts. Ein Beitrag zur Geschichte der modernen Verwaltungswissenschaft. Hamburg: Hansischer Gildenverlag.

Drechsler, W. (2005). The Re-Emergence of 'Weberian' Public Administration after the Fall of New Public Management: The Central and Eastern European Perspective. Halduskultuur, Vol. 6, p. 94-108.

Drechsler, W. (2009). The Rise and Demise of the New Public Management: Lessons and Opportunities For South East Europe. Uprava - Administration, Vol. 7(3), p. 7-27.

Drechsler, W. et al. (eds). (2013). The Past, Present and the Future of Public Administration in Central and Eastern Europe. Bratislava: NISPAcee.

Drechsler, W., Kattel, R. (2008). Towards the Neo-Weberian State? Perhaps, but Certainly Adieu, NPM! The NISPAcee Journal of Public Administration and Policy, Vol. 1(2), p. 95-99.

Dunn, W. N., Miller, D. Y. (2007). A Critique of the New Public Management and the Neo-Weberian State: Advancing a Critical Theory of Administrative Reform. Public Organization Review, Vol. 7(4), p. 345-358.

Gallo, C., Svensson, K. (2019). Victim Support and the Welfare State. London: Routledge.

Guogis, A. (2013a). How Can the New Governance Benefit the World and Lithuania? Central European Political Science Review, Vol. 14, p. 51-77.

Guogis, A. (2013b). What kinds of new branding in administration is necessary to apply in European public and non-profit sectors? A particular reference to Eastern European countries. Responsibility and Sustainability, Vol. 1 (2), p. 1-6.

Hausner, J. (2008). Zarządzanie publiczne. Warszawa: Wydawnictwo naukowe SCHOLAR.

Hood, Ch. (1991). Public Management for All Seasons? Public Administration, Vol. 69 (1), p. 3-19.

Hood, Ch., Dixon, R. (2015). A Government that Worked Better and Cost Less? Evaluating Three Decades of Reform and Change in UK Central Government. New York: Oxford University Press.

Kettle, D. F. (2000). Public Administration at the Millenium: The State of the Field. Journal of Public Administration Research and Theory, Vol. 10(1), p. 7-33.

Kickert, W. J. M., Stillman, R. J. (1996). Changing European States: Changing Public Administration. Public Administration Review, Vol. 56(1), p. 65-67.

Klimovský, D. (2009a). Kameralizmus v perspektíve dnešného poznávania verejnej správy. Slovenská politologická revue, Vol. 9(1), p. 76-88.

Klimovský, D. (2009b). Politics and its impact on the reform processes: The case of public administration reform in Slovakia (1989-2006). In: J. Musil (ed.). Space and Historical Time as Dimensions of Social Change. Praha: Charles University, p. 45-64.

Koht, H., Reinholde, I. (2015). From Pre-Weber to Post-NPM: Challenges to Modernization of Public Administration in Latvia and Norway. In: Kovač, P., Gajdusckek, G. (eds.) Contemporary Governance Models in Central and Eastern Europe. Bratislava: NISPAcee Press.

Kooiman, J. (2000). Societal Governance: Levels, Modes, and Orders of Social-Political Interaction. In: J. Pierre (ed.). Debating Governance: Authority Steering, and Democracy. Oxford: Oxford University Press, p. 138164.

Kovač, P. (2015). Developing New Governance Models and Administrative Practices. In: P. Kovač, G. Gajdusckek (eds.). Contemporary Governance Models in Central and Eastern Europe. Bratislava: NISPAcee Press.

Kuhlmann, S., Fedele, P. (2010). New Public Management in Continental Europe: Local Government Modernisation in Germany, France, and Italy. In: H. Wollmann, G. Marcou (eds.) The Provision of Public Services in Europe. Cheltenham: Edward Elgar, p. 49-74.

Krukowski, K., Siemiński, M. (2018). New Public Management in Organisations Introducing Agricultural Policies in Poland. Management Theory and Studies for Rural Business and Infrastructure Development, Vol. 40, No. 2, p. 206-215.

Lane, J.-E. (1996). Reform in the Nordic Countries. Public Sector Reform. London: Sage, p. 188-208.

Lane, J.-E. (2000). New Public Management. London: Routledge.

Lapuente, V., Van de Walle, S. (2020). The effects of new public management on the quality of public services. Governance, Vol. 33, p. 461-475.

Malíková, L., Jacko, T. et al. (eds.) (2013). New Public Management a Slovensko: Podoby a aplikácia princípov. Bratislava: Univerzita Komenského.

Mayo, E. (1945). The Social Problems of an Industrial Civilization. Boston: Harvard University Press.

Meneguzzo, M. et al. (2011). Public sector modernization trends of the member states of European Union: 
Iveta Reinholde, Arvydas Guogis, Vainius Smalskys, Skaidrė Žičkienė, Daniel Klimovsky

Trajectories of reforms in Italy and Romania, MPRA Paper, No. 27805.

Merton, R. K. (1940). Bureaucratic Structure and Personality. Social Forces, Vol. 17(6), p. 560-568.

Minkevičius, A., Smalskys, V. (2008). Valstybès tarnyba užsienio šalyse: raida ir tendencijos. Vilnius: MRU leidybos centras.

Nemec, J. (2008). Public Management Reforms: Slovakia. In: Bouckaert, G. et al. (eds.) Public Management Reforms in CEE. Bratislava: NISPAcee, p. 342-369.

Osborne, D., Gaebler, T. (1992). Reinventing Government: How the Entrepreneurial Spirits is Transforming the Public Sector. New York: Addison-Wesley.

Osborne, S. P. (2006). The New Public Governance? Public Management Review, Vol. 8(3), p. 377-387.

Osborne, S. P. (2010). The New Public Governance. Emerging Perspectives on the Theory and Practice of Public Governance. London: Routledge.

Patapas, A. (2010). Tradicinis (hierarchinis) viešasis administravimas. In: V. Smalskys (ed.). Viešasis valdymas. Vilnius: Mykolo Romerio universiteto Leidybos centras.

Pinterič, U. (2011). Slovenian police as life or budget warden. In: V. Žúborová, et al. (eds.) Social responsibility in 21st century. Ljubljana: Vega, p. 146-157.

Pollitt, Ch. et al. (eds.) (2007). New Public Management in Europe. Basingstoke: Palgrave Macmillan.

Pollitt, Ch., Bouckaert, G. (2004). Public Management Reform: A Comparative Analysis. 2nd ed. Oxford: Oxford University Press.

Pollitt, Ch., Bouckaert, G. (2011). Public Management Reform. A Comparative Analysis: New Public Management, Governance, and the Neo-Weberian State. Oxford: Oxford University Press.

Pollitt, C., Bouckaert, G. (2017). Public management reform: A comparative analysis-into the age of austerity. Oxford: Oxford University Press.

Poviliūnas, A. (2003). Tyrimas dalyvaujant kaip socialinių inovacijų technologija. Sociologija: Mintis ir veiksmas, Nr. 1, p. $42-48$.

Puškorius, S. (2002). 3E koncepcijos plètra. Viešoji politika ir administravimas, Nr. 3, p. 31-38.

Raipa, A. (ed.) (2009). Viešasis administravimas: istorinè raida, turinys, pokyčiai. Ivadas $i$ viešaji valdyma. Kaunas: Technologija.

Rugge, F. (2003). Administrative Traditions in Western Europe. In: B. G. Peters, J. Pierre (eds.). Handbook of Public Administration. London: Sage, p. 177-189.

Rupnik, J. (2000). Eastern Europe: The International Context. Journal of Democracy, Vol. 11 (2), p. 115-129.

Rutgers, M. R. (1997). Beyond Woodrow Wilson: The Identity of the Study of Public Administration in Historical Perspective. Administration and Society, Vol. 29(3), p. 276-299.

Rutgers, M. R. (ed.) (2003). Tracing the Idea of Public Administration: Towards a Renaissance of Public Administration? Retracing Public Administration. New York: Elsevier Science, p. 1-36.

Sapetkaitè, V. (2014). Kremliaus pasakos ir tos „niekšiškos“ Baltijos šalys. Veidas, Nr. 38, p. 18-23.

Selznick, P. (1943). An Approach to a Theory of Bureaucracy. Administrative Science Review, Vol. 8(1), p. 47-54.

Schick, A. (1998). Why Most Developing Countries Should Not Try New Zealand Reforms. World bank.

Siami-Namini, S. (2020). The New Public Management: Administrative Reform in Iran (February 8). Available at SSRN: https://ssrn.com/abstract=3534437 or http://dx.doi.org/10.2139/ssrn.3534437

Simon, H. A. (1976). Administrative Behavior. New York: Free Press.

Smalskys, V. (2007). „Naujosios viešosios vadybos“ igyvendinimo problemos kontinentinėje Europoje. In: A. Raipa (ed.). Naujoji viešoji vadyba. Kaunas: Technologija.

Smalskys, V. (2009). Viešojo valdymo modernizavimas. In: A. Raipa (ed.). Itvadas $i$ viešajị valdyma. Kaunas: Technologija.

Smalskys, V. et al. (2017). Public Sector Reforms in Lithuania Since 1990. Public Administration Reforms in Eastern European Union Member States. Post Accession Convergence and Divergence. Vilnius: Mykolas Romeris University and Ljubljana: University of Ljubljana Faculty of Administration.

Svara, J. H. (2001). The Myth of the Dichotomy: Complementarity of Politics and Administration in the Past and Future of Public Administration. Raleigh: North Carolina State University.

Szczepankowski, R. (2009). Administracja i polityka w ujęciu Woodrowa Wilsona. In B. Kudrycka, et al. (eds). Nauka administracji. Warszawa: Wolters Kluwer Polska.

Vareikytè, A. et al. (2006). Socialiniu paslaugu tobulinimas Lietuvos savivaldybèse. Vilnius: MRU Leidybos centras.

Weber, M. (1976). Wirschaft und Gesellschaft. Grundriss der Verstehenden Soziologie. Fünfte, revidierte Auflage mit Textkritischen Erläuterungen herausgegeben von Johannes Winckelmann. 2. Halbband. Tübingen: 
J. C. B. Mohr (Paul Siebeck).

Wieworka, M. (2013). Social conflict. Current Sociology, Vol. 61(5), p. 699-700.

Wincott, D. (2013). The (Golden) Age of Welfare State: Interrogating a Conventional Wisdom. Public Administration, Vol. 91(4), p. 806-822.

Wollmann, H., Thurmaier, K. (2011). Reforming Local Government Institutions and the New Public Management in Europe and in the US. In: K. Moosberger, et al. (eds.). Oxford Handbook of Urban Politics. Oxford: Oxford University Press, p. 179-209.

Zawicki, M. (2011). Nowe zarzadzane publiczne. Warszawa: PWE, p. 37-38.

Iveta Reinholde - PhD in Political Science, associated professor at Department of Political Science, University of Latvia, Riga, Latvia.

E-mail: Iveta.Reinholde@lu.lv

Arvydas Guogis - professor, doctor of Social Sciences, hab. procedure (Management and Administration), Institute of Public Administration, Mykolas Romeris University, Lithuania.

E-mail: arvydasg@mruni.eu 